\title{
The Effect of Problem-based Learning Model Modified by Cognitive Load Theory on Mathematical Problem Solving Skills
}

\author{
Maulida Nur Zahara ${ }^{1 *}$, Aan Hendrayana ${ }^{1}$, Aan Subhan Pamungkas ${ }^{1}$ \\ ${ }^{1}$ Sultan Ageng Tirtayasa University, Serang, Indonesia. \\ *Corresponding Author, e-mail: maulidanurzahara@gmail.com \\ DOI: $10.18326 /$ hipotenusa.v2i2.41-55
}
Article submitted
: July $1^{\text {st }}, 2020$
Article reviewed
: September $17^{\text {th }}, 2020$
Article published
: December $1^{\text {st }}, 2020$

\begin{abstract}
The background of the research is based on the fact that problem-solving skills and its process is still low so that those create overload information. Another way to overcome this problem is to use a problem-based learning model that concerns the cognitive load theory. This study aims to determine how students' problem-solving skills are modified using a problem-based learning model limited by cognitive load theory. This research method uses a combination of research methods, namely quantitative as primary data and qualitative as secondary data. This study's population are all students of grade VII Junior High School accredited A in Tangerang Regency. The sampling technique used is random cluster sampling, and the selected sample is 60 students of Grade VII SMP Negeri 3 Cikupa, which is divided into experimental class and control class. This research's instruments are 5 short essay tests and nontests, a questionnaire, and an interview. Based on data analysis's result, it can be concluded that the achievement and improvement of students' mathematical problemsolving abilities which use problem-based learning model modified by cognitive load theory, are better than for those using problem-based learning generally.
\end{abstract}

Keywords: problem-based learning, problem-solving, cognitive load theory 


\section{INTRODUCTION}

The development of digital technology in the current Industry 4.0 era has brought changes and impacts greatly. It affects various aspects of human life, including the education sector (Buteau \& Muller, 2017; Panero \& Aldon, 2016; Putrawangsa \& Hasanah, 2018). One of the challenges that must be faced in changing life in this era of revolution 4.0 is improving the quality of human resources that are capable of competing in this global era. The quality of human resources can be gained from the quality of education as well so that the education unit should be able to provide a set of plans and arrangements regarding the objectives, content, and learning materials, as well as the methods used as guidelines for implementing learning activities to achieve certain educational goals (Marlina \& Jayanti, 2019; Parwati, 2019; Pratiwi \& Fasha, 2015; Sujadi, 2018).

To answer the Industrial Revolution 4.0 era's challenges, the educational world should adopt the 21st-century learning process. In fact, education is growing continuously in line with human civilization development, which is supported by science and technology rapidly. In this century, people are required to have: critical thinking and problem solving, communication, collaboration and creativity, and innovation. (Marlina \& Jayanti, 2019; Parwati, 2019; Putrawangsa \& Hasanah, 2018).

In the world of education, students' abilities are trained through problems so that they are able to improve their various competencies (Sumartini, 2016). Problem-solving is basically the main goal of learning mathematics. However, based on several previous studies, problem-solving ability skills are still low. Students prefer to memorize formulas instead of understanding concepts so that learning outcomes are more important than their process, and they are problematic when facing problem-solving on mathematics questions. Then, teachers take part in implementing learning methods, which make them less interested in solving a mathematical problem (Hadi \& Radiatul, 2014; Sumartini, 2016; Ulya, 2015).

A good learning model is needed to improve students' problem-solving. One of the learning models that can be developed and projected to improve problem-solving skills is the problem-based learning model. Problem-based learning is learning that started and centered on a problem (Davita \& Pujiastuti, 2020; Fatimah, 2012; Novikasari, 2020). 
In problem-based learning, students must identify conscious and unconscious material and learn to solve a problem; students answer the questions based on their information memory.

Moreover, when someone is faced with non-routine problems (problem-solving), it is found that his working memory is overloaded (Nurfatanah; Rusmono; Nurjannah, 2019; Solikah \& Himmah, 2019; Sweller, 1988; Ulya, 2015). People have limited managing information in their brains so that when they cannot manage it properly, there will be an overload. The condition of overload information is called cognitive load (Hendrayana, 2015). Factors that affect the cognitive load on people's condition are level of complexity of the problem (intrinsic load), mediators' actions that help to solve the problem (extraneous load), and involvement of sense are constructing informational process, working memory, and long-term memory (germane load) (Hendrayana, 2015; Mayer \& Moreno, 2010; Panse et al., 2018).

To minimize overloading conditions caused by problem solving's process in the problem-based learning model, several innovations are needed in this model. One of them is to pay attention to students' cognitive conditions. Therefore, researchers will use a problem-based learning model on the cognitive load theory.

This model's reason is that the learning process shall increase problem-solving too and eliminate students' cognitive load. (Fitriadi et al., 2017; Mikrayanti, 2012; Sumartini, 2016). The researchers focus on reducing extraneous loud, namely improper teaching methods, which cause cognitive load on students.

The research is located in Tangerang Regency, one of 8 cities/regencies in Banten Province. Tangerang people mostly work in the industrial sector because the area is surrounded by many factories. But, according to the Ministry of Education and Culture, Tangerang Regency receives the fourth rank in the mathematics National Examination (UN) results of Junior High School in Banten, 2019.

The first rank is South Tangerang, while the second is Tangerang City. Although it is close to Tangerang City and South Tangerang, the quality of education is quite different. Thus, low mathematics UN result means that the ability to solve mathematical problems is low too. Researchers want to improve the mathematical problem-solving abilities of Junior High School students in the Tangerang Regency. 
Based on the background above, the research problems are: (1) How are the students' problem-solving skills when using a problem-based learning model modified by cognitive load theory? (2) Are its skills better than a general problem-solving model?

The purpose of this research is to find out how problem-solving works when using a problem-based learning model modified by cognitive load theory.

The benefit of this research is that a problem-based learning model modified by cognitive load theory to improve students' problem-solving abilities can be used as a guide in implementing mathematics learning; can provide information and suggestion on its implementation in order to improve schools' quality, especially in mathematics; and to know its effectiveness so that it gives the positive impacts on mathematics subject and also increase students' problem-solving skills.

\section{METHOD}

This type of research uses the research data combination method (mixed methods). Cresswell (in Sugiyono, 2011) argues that a combination research method is an approach in research that combines or links between quantitative and qualitative research methods.

The research method in this research is a concurrent embedded design. Quantitative and qualitative are used simultaneously or together, but in different portions, there are primary and secondary methods (Sugiyono, 2011). Researchers use quantitative as a primary method and qualitative as a secondary method.

The use of this method combination optimizes researchers to reveal the research targets, as well as to obtain complete, valid, reliable, and objective data information. By using a combination method, the weaknesses in both quantitative and qualitative methods can be minimized.

The $\mathrm{X}$ variable (free) in this research is a problem-based learning model modified by cognitive load theory, while the Y (dependent) variable is the problem-solving skills. Then, the researchers will use the mean test method. The test is used to test the truth of the hypothesis.

\section{Research Subject}

The population in this research is all students of Grade VII accredited A Junior High School in Tangerang Regency. The sampling method is cluster random sampling. Then, 
the sample is SMP Negeri 3 Cikupa. SMP Negeri 3 Cikupa has a national mathematics test score of 46.92 and higher than the other schools. Therefore, the researcher uses 1 control class and 1 experimental class.

\section{Data Collection Procedure}

The data collection procedure is divided into 3 parts. The first is the preparation stage. The second is the implementation stage, and the third is the data analysis stage. The preparation stage is making good instruments, validating the required instruments, identifying data collection procedures, and determining hypotheses.

The implementation phase begins by giving a pretest to the experimental class and control class, followed by the learning process, then giving a posttest. Furthermore, to obtain more in-depth data, the researchers gave a questionnaire and conducted an interview.

The last stage is the data analysis stage. Test and non-test analysis' results instruments are used to determine the effect of the problem-based learning model modified by cognitive load theory on students' problem-solving skills.

\section{Instrument}

The instruments are test and non-test. The test questions consist of 5 short essay questions, while the non-test is questionnaires and interviews, which questioned about the learning process, students' feelings, and students' results on the problem-solving skills' indicator during the class. Moreover, the instrument of the research is a valid and reliable instrument.

\section{Data Analysis Technique}

Data analysis simplifies data into a form that is easier to be read and interpreted. (Singarimbun \& Effendi, 2006). The analysis takes two stages, namely using quantitative methods and qualitative methods.

The quantitative data is analyzed using the N-Gain test and the mean test (T-test). Before taking its result, the prerequisite test is carried out earlier, namely the normality test and the homogeneity test. The T-test formula is: 


$$
t_{\text {score }}=\frac{X_{1}-X_{2}}{\sqrt{\frac{\left(n_{1}-1\right) s_{i^{2}}+\left(n_{2}-1\right) s_{i^{2}}}{n_{1}+n_{2}-2}\left(\frac{1}{n_{1}}+\frac{1}{n_{2}}\right)}}
$$

Based on this formula, there are 3 types of scores that we must prepare first, namely:

$\mathrm{Xi}=$ the average score/group i's score

$\mathrm{ni}=$ Total respondents of group $\mathrm{i}$

$s_{i^{2}}=$ group i's variants

The qualitative data of a questionnaire are analyzed using the average percentage of student answers, by the formula:

$$
\bar{P}_{i}=\frac{\sum f_{i} P_{i}}{n} * 100 \%
$$

Explanation:

$\bar{P}_{i}=$ The average of students' answers on 'i' statement

$f_{i}=$ The frequency of students' answers on 'i' statement

$P_{i}=$ The percentage of students' answer on 'i' statement

$n=$ The total of respondents

\section{RESULTS AND DISCUSSION}

Students in the experimental class and the control class conduct a pretest to examine whether both classes have a similar basic understanding of the delivered materials. The average score, standard deviation, variance, and maximum score of experimental class and control class students' pretest data are presented in Table 1 as follows.

Table 1. Pretest result

\begin{tabular}{lcc}
\hline & Experiment & Control \\
\hline Average & 12,97 & 12,9 \\
Standard Deviation & 5,59 & 4,89 \\
Variance & 31,34 & 23,96 \\
Maximum Score & 25 & 23 \\
\hline
\end{tabular}


After obtaining data of students' pretest from both classes, then it will be conducted hypothesis testing using the T-test with alpha 0.05 . The result of $t_{\text {count }}$ is 0.48 , because $t_{\text {count }}>$ alpha, so $\mathrm{H}_{0}$ is accepted, which means that there is no significant difference in the ability of the previous knowledge between the experimental class and the control class. So those classes have similar previous knowledge.

After the learning process for approximately 4 weeks, the next step is to see the difference from the classes' implemented learning model. In order to know the difference, the researchers give a final test or posttest. The average score, standard deviation, variance, and maximum score of post-test data are presented in Table 2.

The researcher analyzes it based on each indicator of students' mathematical problem-solving skills first, which included the ability to identify known and asked information, compile mathematical models, solve mathematical models, and check the correct conclusion.

Table 2. Posttest Results Data

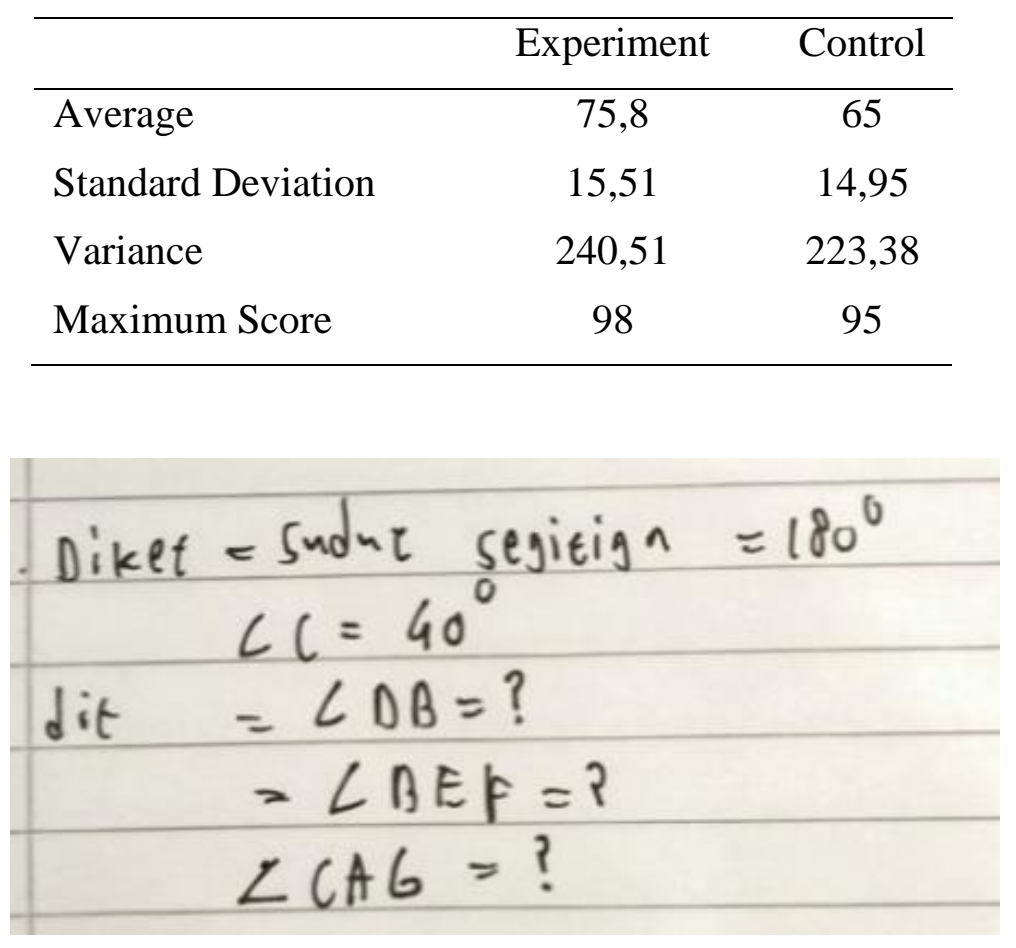

Figure 1. The ability to identify elements that are known and asked by the experimental class students in question number 1 
Jurnal Hipotenusa, 2 (2), December 2020

Maulida Nur Zahara, Aan Hendrayana, and Aan Subhan Pamungkas

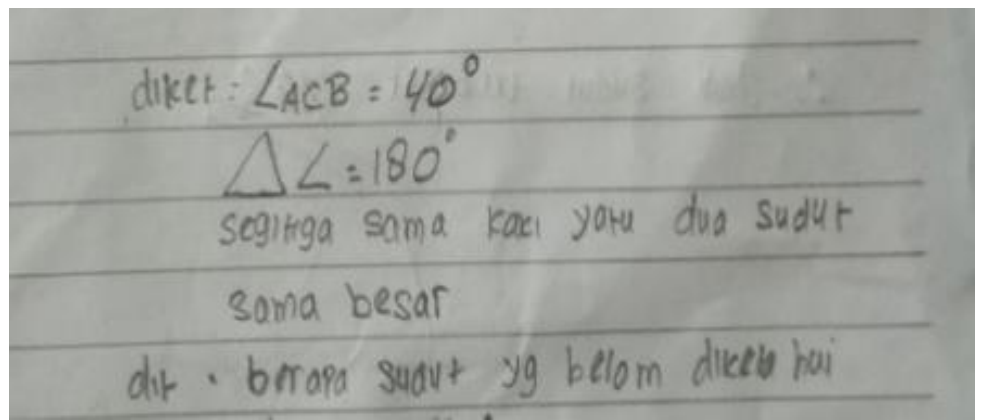

Figure 2. The ability to identify control class students in question no.1

Figure 1 and Figure 2 below show the difference in the ability to identify the elements that are known and asked among students in the experimental class and students in the control class.

Based on Figure 1 and Figure 2, it can be concluded that the ability to identify known and asked elements of the experimental class is better than the control class. The experimental class writes it briefly and clearly, but the control class is contrasted to it. Furthermore, on the indicators of compiling a mathematical model, the different answers of two classes are presented in Figure 3 and Figure 4 as follows.

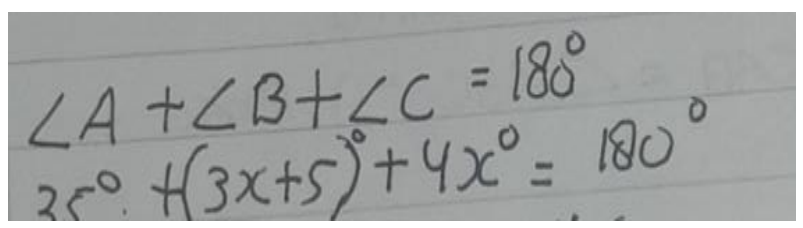

Figure 3 . The ability to compile a mathematical model for the experimental class students on the question no 2

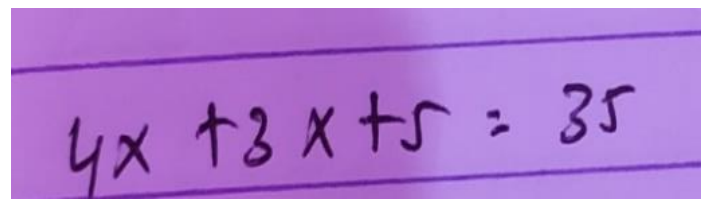

Figure 4. The ability to compile a mathematical model on the control class in question no 2

Based on Figure 3 and Figure 4, it can be concluded that the ability to compile mathematical models in the experimental class is better than the control class. The experimental class writes a mathematical model on the questions correctly, while the control is missed. Furthermore, on the indicators of completing the mathematical model, 
Jurnal Hipotenusa, 2 (2), December 2020

Maulida Nur Zahara, Aan Hendrayana, and Aan Subhan Pamungkas

the experimental class and control class's differences answers are presented in Figure 5 and Figure 6 as follows.

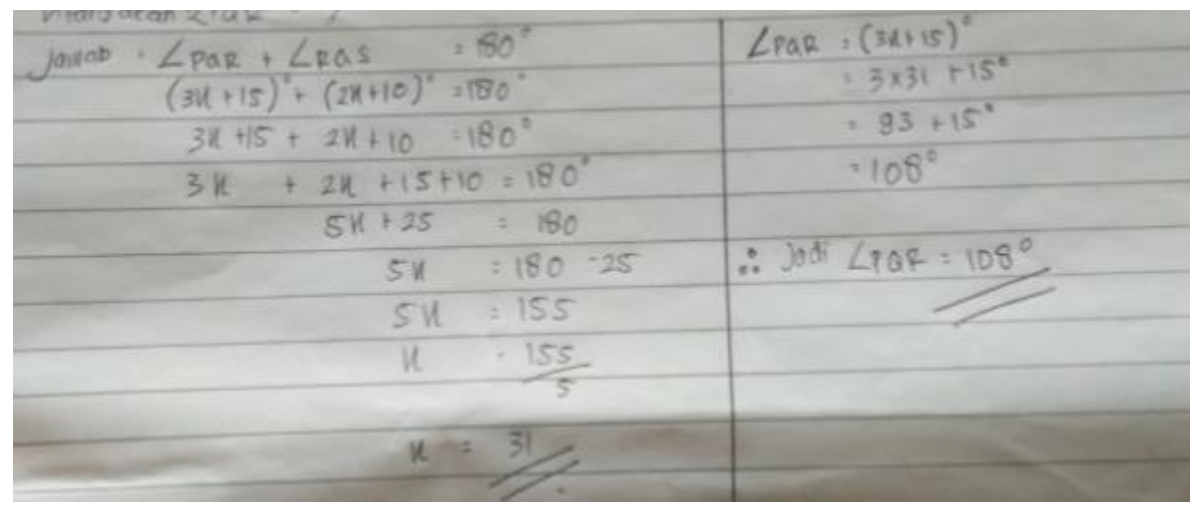

Figure 5. The ability to solve the mathematical model in experimental on question number 4

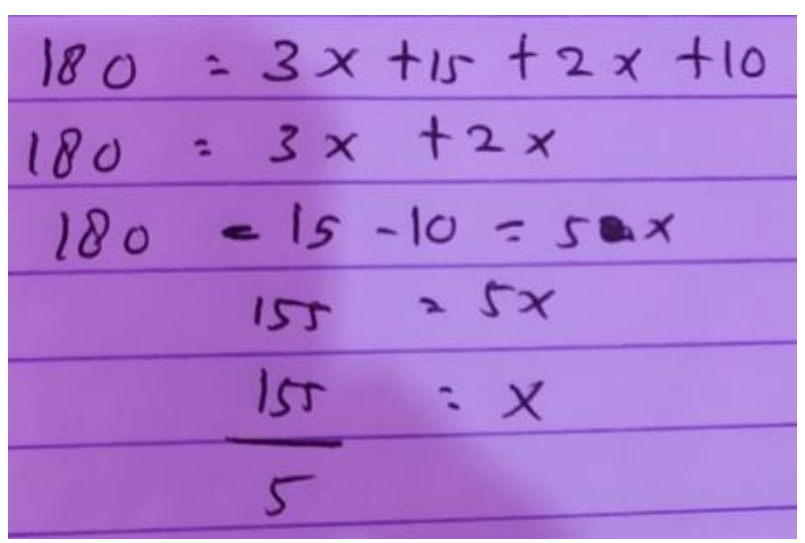

Figure 6. Students' ability to solve the mathematical model in the control class on question no 4

Based on Figure 5 and Figure 6, it can be said that the ability to solve the mathematical model of the experimental class is better than the control class. The experimental class writes the mathematical model's answer correctly and in detail, while the control class could not solve the answers. Moreover, on the indicators of checking the correctness of the conclusion, both classes' differences are presented in Figure 7 and Figure 8 as follows. 


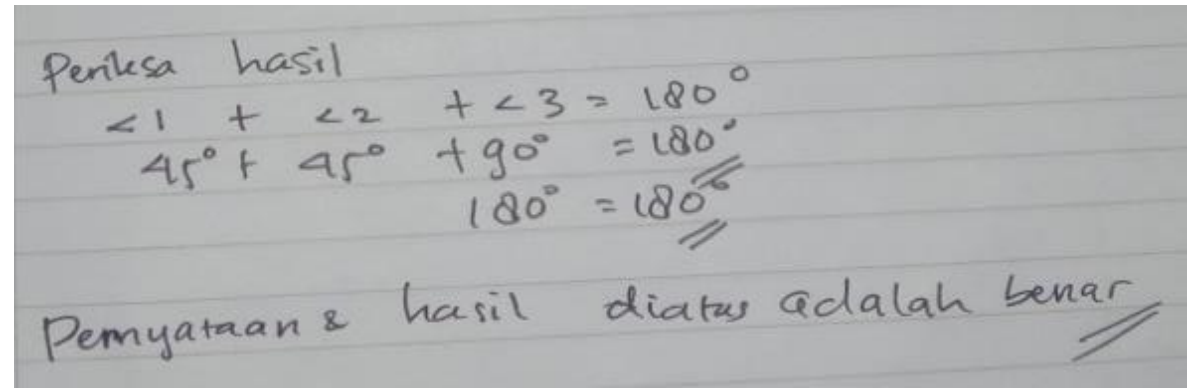

Figure 7. The ability to check the correctness of the conclusion in the experimental class on question no.5

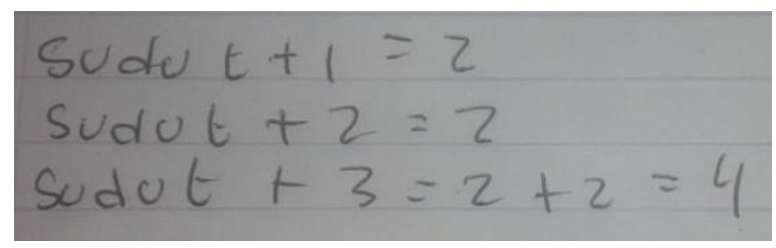

Figure 8 . The ability to check students' correctness of the conclusion in the control class on question no.5

Based on Figure 7 and Figure 8, it can be seen that the ability to check the correctness of the experimental class conclusion is better than the control class. The experimental class re-checks and writes arguments to the questions, while the control class does not re-check the answer.

Statistical calculations are needed to test the hypothesis' truth so that the results will be are accurate. The test is the achievement hypothesis test and the increase of hypothesis tests. The achievement hypothesis test uses the T-test formula with an alpha of 0.05. The result of $\mathrm{t}_{\text {count }}$ is 0.004 , because $\mathrm{t}_{\text {count }}<$ alpha, then $\mathrm{H}_{0}$ is rejected, so $\mathrm{H}_{1}$ is accepted, which means that the achievement of mathematical problem-solving ability in the experimental class is better than the control class.

To test the increase in the hypothesis, the researcher used the T-test formula with an alpha of 0.05 . The result of tcount is 0.003 , because tcount <alpha then $\mathrm{H}_{0}$ is rejected and it results in $\mathrm{H}_{1}$ being accepted, which means that the increase in mathematical problem-solving ability in the experimental class is better than the control class.

Learning on lines and angles are in 4 weeks. Researchers give worksheets and also practice or projects. Experimental class worksheets always refer to extraneous load deduction factors. This helps decrease students' cognitive load in the experimental class. 
This is in line with Hendrayana's research; he states that minimized extraneous early is important so that students are able to have a long-term memory (Hendrayana, 2015).

During the learning process, the experimental class students seem to be more enthusiastic and active, asking questions than the control class students. Control class students tend to be quiet and rarely ask many questions, even when practising the condition of the control class is still conducive and silent. In the learning process, the experimental class students can solve mathematical problems and finish the given assignments better and faster than the control class. This is in line with the research conducted by Sumartini, who has concluded that the experimental class, which uses a problem-based learning model, is better at solving problems than the control class (Sumartini, 2016).

Based on inferential statistical analysis results, the experimental class has a better final achievement than the control class. The results can be seen from the differentiation between experimental class' students and control class' students on their problem-solving ability's average. Therefore, the problem-based learning model modified by cognitive theory is better than the general problem-based learning model on students' mathematical problem-solving skills.

The control class gets a higher cognitive load than the experimental class. According to Sweller, excessive cognitive load arises from given irregular problems (problem-solving) (Sweller, 1988). In other words, if the learning model focuses on students' cognitive load, students will have the opportunity to improve their mathematical problem-solving skills.

The analysis results of this research indicate that the problem-based learning model modified by cognitive load theory has a positive impact on students' mathematical problem-solving skills. Researchers give the appropriate teaching methods to reduce students' extraneous cognitive load. This illustrates that the more perfect of problembased learning model concerned to the cognitive load theory (extraneous load's deduction) used by the teachers, the ideal student's problem-solving skills achievement. This is similar to Mayer \& Moreno's statements that the effective learning process in improving problem-solving skills happens if its learning reduces extraneous cognitive load (Mayer \& Moreno, 2010). Indeed, the problem-based learning model is proven to 
enhance students' problem-solving skills (Gunantara et al., 2014; Jailani et al., 2017; Maqfiroh, 2016).

However, by focusing on the students' cognitive load because of teachers' misconception in the teaching-learning process, the problem-based learning models will effectively increase problem-solving skills. This is similar to the previous research's results found that problem-based learning which focused on students' cognitive load, has proven to give good results (Fitriadi et al., 2017; Hendrayana, 2015; Mayer \& Moreno, 2010).

\section{CONCLUSION}

Based on the analysis and discussion's results, the researchers conclude that the problem-based learning model modified by cognitive load theory can improve mathematical problem-solving skills. It can be seen from its high N-Gain score. It means that there is a significant increase in mathematical problem-solving skills. Therefore, mathematical problem-solving skills on the problem-based learning model modified by cognitive load theory are better than the general problem-based model only.

\section{REFERENCES}

Buteau, C., \& Muller, E. (2017). Assessment in Undergraduate Programming-Based Mathematics Courses. Digital Experiences in Mathematics Education, 3(2), 97114. https://doi.org/10.1007/s40751-016-0026-4

Davita, P. W. C., \& Pujiastuti, H. (2020). Anallisis Kemampuan Pemecahan Masalah Matematika Ditinjau Dari Gender. Kreano, Jurnal Matematika Kreatif-Inovatif, 11(1), 110-117. https://doi.org/10.15294/kreano.v11i1.23601

Fatimah, F. (2012). Kemampuan Komunikasi Matematis Dalam Pembelajaran Statistika Elementer Melalui Problem Based-Learning. Cakrawala Pendidikan, TH.XXXIV(2), 267-277.

Fitriadi, S., Suharto., \& Trapsilasiwi, D. (2017). Pengembangan Perangkat Pembelajaran Matematika Model Problem Based Learning pada Materi Barisan dan Deret Aritmetika Kelas X SMA dengan Memperhatikan Beban Kognitif. Jurnal Edukasi, IV(1). 
Gunantara, G., Suarjana, M., \& Riastini, N. (2014). Penerapan Model Pembelajaran Problem Based Learning untuk Meningkatkan Kemampuan Pemecahan. Jurnal Mimbar PGSD Universitas Pendidikan Ganesha, 2(1).

Hadi, S., \& Radiatul. (2014). Metode Pemecahan Masalah Menurut Polya untuk Mengembangkan Kemampuan Siswa dalam Pemecahan Masalah Matematis di Sekolah Menengah Pertama. EDU-MAT Jurnal Pendidikan Matematika, 2(1), 5361.

Hendrayana, A. (2015). Mengatasi Cognitive Load Pada Anak. FKIP Untirta Publisher. Jailani, J., Sugiman, S., \& Apino, E. (2017). Implementing the problem-based learning in order to improve the students' HOTS and characters. Jurnal Riset Pendidikan Matematika, 4(2), 247. https://doi.org/10.21831/jrpm.v4i2.17674

Maqfiroh, F. (2016). MENINGKATKAN KOMUNIKASI MATEMATIKA MELALUI MODEL PEMBELAJARAN PBL (PROBLEM BASED LEARNING) BERBASIS CIRC (COOPERATIVE INTEGRATED READING AND COMPOSITION. Universitas Muhammadiyah Surakarta.

Marlina, W., \& Jayanti, D. (2019). 4C dalam Pembelajaran Matematika untuk Menghadapi Era Revolusi Industri 4.0. SENDIKA Vol. 5 No. 1, 392-396.

Mayer, R. E., \& Moreno, R. (2010). Reduce Extraneous Cognitive Load and Manage Intrinsic Cognitive Load during Multimedia Learning. Cambridge University Press.

Mikrayanti. (2012). MENINGKATKAN KEMAMPUAN PENALARAN DAN KOMUNIKASI MATEMATIS SISWA SEKOLAH MENENGAH ATAS MELALUI PEMBELAJARAN BERBASIS MASALAH :Studi Kuasi Eksperimen pada Siswa SMA di Kabupaten Bima. Universitas Pendidikan Indonesia.

Novikasari, I. (2020). Pre-service teacher's mathematical knowledge for teaching in problem-based learning. JRAMathEdu (Journal of Research and Advances in Mathematics Education), 5(2), 160-174. https://doi.org/10.23917/jramathedu.v5i2.10556

Nurfatanah; Rusmono; Nurjannah. (2019). Kemampuan Pemecahan Masalah Matematis Siswa Sekolah Dasar. Prosiding Seminar Dan Diskusi Nasional Pendidikan Dasar, 
Jurnal Hipotenusa, 2 (2), December 2020

Maulida Nur Zahara, Aan Hendrayana, and Aan Subhan Pamungkas

546-551. https://doi.org/10.31227/osf.io/a5qyh

Panero, M., \& Aldon, G. (2016). How Teachers Evolve Their Formative Assessment Practices When Digital Tools Are Involved in the Classroom. Digital Experiences in Mathematics Education, 2(1), 70-86. https://doi.org/10.1007/s40751-016-0012$\mathrm{X}$

Panse, A., Alcock, L., \& Inglis, M. (2018). Reading Proofs for Validation and Comprehension: an Expert-Novice Eye-Movement Study. International Journal of Research in Undergraduate Mathematics Education, 4(3), 357-375.

https://doi.org/10.1007/s40753-018-0077-6

Parwati, N. N. (2019). Adaptasi Pembelajaran Matematika di era Revolusi Industri 4.0. SENAMA PGRI, 1-11.

Pratiwi, U., \& Fasha, E. F. (2015). Pengembangan Instrumen Penilaian Hots Berbasis Kurikulum 2013 Terhadap Sikap Disiplin. Jurnal Penelitian Dan Pembelajaran IPA, 1(1), 123. https://doi.org/10.30870/jppi.v1i1.330

Putrawangsa, S., \& Hasanah, U. (2018). Integrasi Teknologi Digital dalam Pembelajaran di Era Industri 4.0 Kajian dari Perspektif Pembelajaran Matematika. Jurnal Tatsqif, 16(1), 42-54.

Singarimbun, M., \& Effendi, S. (2006). Metode Penelitian Survei. LP3ES.

Solikah, A., \& Himmah, W. I. (2019). Keefektifan Model Pembelajaran Means Ends Analysis Dengan Strategi Heuristik Terhadap Kemampuan Pemecahan Masalah Matematika. Hipotenusa : Journal of Mathematical Society, 1(1). https://doi.org/10.18326/hipotenusa.v1i1.3278

Sugiyono. (2016). Metode Penelitian Kuantitatif, Kualitatif, dan R\&D. Alfabeta.

Sujadi, I. (2018). Peran Pembelajaran Matematika pada Penguatan Nilai Karakter Bangsa di Era Revolusi Industri 4.0. Silogisme, 1-13.

Sumartini, T. . (2016). Peningkatan Kemampuan Pemecahan Masalah Matematis Siswa melalui Pembelajaran Berbasis Masalah. Jurnal Pendidikan Matematika, 5(2), $148-158$.

Sweller, J. (1988). Cognitive Load During Problem Solving. Cognitive Science, 12(2), 
Jurnal Hipotenusa, 2 (2), December 2020

Maulida Nur Zahara, Aan Hendrayana, and Aan Subhan Pamungkas

$257-285$.

Ulya, H. (2015). Hubungan Gaya Kognitif dengan Kemampuan Pemecahan Masalah

Matematika Siswa. Jurnal Konseling GUSJIGANG, 1(2). 